\title{
Urinary calcium excretion pattern in preeclampsia
}

\author{
Rai $S^{1}$, Upadhyaya $\mathbf{I}^{1}$, Malla $K^{1}$, Baral $\mathbf{G}^{1}$ \\ ${ }^{1}$ Paropakar Maternity and Womens' Hospital, Thapathali, Kathmandu
}

Received: 17-Oct-2016; Accepted: 17-Dec-2016

Aims: This study aimed to evaluate the urinary calcium excretion pattern in preeclampsia and to establish the relation between severity of preeclampsia and urinary calcium excretion

Methods: This was a case-control study conducted at Paropakar Maternity and Women's Hospital, Kathmandu from January to June 2015. There were 88 patients equally divided in each group. 24 hours urine calcium was analyzed by ortho-cresophthalincomplexone method (OCPC) and urinary proteinuria was analyzed bedside by sulphosalicylic acid. Results were analyzed using SPSS 17. P value of $<0.05$ was considered as significant.

Results: Preeclampsia was found to occur commonly among the nulliparous patients (59\%). The patients with MAP with $\geq$ $110 \mathrm{mmHg}$ excreted less calcium in their urine in comparison to the patient with MAP $<110 \mathrm{mmHg}(73.55 \mathrm{mg} / 24 \mathrm{hrs}$ VS 92.79 $\mathrm{mg} / 24 \mathrm{hr})$. Daily calciuria was decreased with the increase in proteinuria $(91.43 \mathrm{mg}, 76.19 \mathrm{mg}$ and $54.02 \mathrm{mg}$ in $1+, 2+$ and $3+$ respectively). The 24 hours urine calcium excretion in term preeclamptic patient was significantly reduced in compared to the normotensive term pregnant women $(77.92 \mathrm{mg} \pm 48.61 \mathrm{mg}$ VS $117.66 \mathrm{mg} \pm 69.21 \mathrm{mg}, \mathrm{p}<0.001)$.

Conclusions: Preeclamptic patients excrete significantly lower amounts of calcium in urine and it may be a marker of the severity of preeclampsia.

Keywords: calciuria, preeclampsia, pregnancy

\section{INTRODUCTION}

The preeclampsia is diagnosed when the pregnant woman who is previously normotensive presents with high blood pressure $(\geq 140 / 90 \mathrm{mmHg})$ after the $20^{\text {th }}$ week of gestation along with the presence of significant proteinuria (>300mg in $24 \mathrm{hrs}$ ). ${ }^{1}$ Preeclampsia is a major cause of maternal and fetal morbidity and mortality. Incidence of preeclampsia is $7-10 \%$ of all pregnancies ${ }^{2}$, and $4-18 \%$ in developing countries..$^{3-5}$ In this institute, the incidence was $3 \%$ in the year 2070/071 BS (2014 AD).

Preeclampsia is a multisystem disorder affecting hepatic, hematologic, renal, cardiovascular and cerebrovascular systems. ${ }^{19}$ Alteration of the calcium metabolism occurs in preeclampsia that is associated with abnormal calcium regulation. ${ }^{20}$ This alteration

\section{CORRESPONDENCE}

Dr. Snigdha Rai,

Senior House Officer,

Paropakar Maternity and Womens' Hospital, Thapathali

Kathmandu;

Cell\# 9851195477 ,

Email: snigdha_raj@hotmail.com in calcium metabolism is characterized by changes in the serum level of total and ionized calcium as well as urinary calcium excretion. ${ }^{21}$ In preeclampsia, anatomical changes occur in glomeruli, along with the changes in renal perfusion and glomerular filtration rate, as a result of increased arteriolar resistance and ultrafiltration coefficient that contributes to the increased tubular reabsorption of calcium, resulting in hypocalciuria. ${ }^{6}$

The objective of this study was to evaluate the amount of urinary calcium excretion in preeclamptic patients and to determine the severity of preeclampsia in relation to urinary calcium level.

\section{METHODS}

This was a hospital based case control study of 88 patients in the duration of 6 months from January to June 2015at Paropakar Maternity and Women's Hospital, Kathmandu. Singleton term pregnant women were included in the study while the patient with known case of chronic hypertension and those with history of chronic liver disease, malnutrition, chronic renal disease, thyroid and parathyroid disease, immunological disease and other comorbidities were excluded. 
Approval for the study was taken from the ethical board of the hospital and verbal as well as written informed consent was taken.

Mean Arterial Pressure was calculated using the formula

MAP $=$ diastolic $B P+\frac{\text { systolic } B P-\text { diastolic } B P}{3}$

Proteinuria was tested at bedside by adding 3 drops of $20 \%$ sulphosalicylic acid in $3 \mathrm{ml}$ of patient's urine. Calcium level of urine sample analyzed in clinical lab by the colorimetric method using semi analyzer and estimated by the OCPC method at a wavelength of $575 \mathrm{~nm}(550-590 \mathrm{~nm})$. The formula for calcium estimation:

Calcium Conc. $\left(\frac{\mathrm{mg}}{\mathrm{dl}}\right)=\frac{\text { Reading of test material }}{\text { Reading of standard }} \times$ Conc. of Standard $\left(10 \frac{\mathrm{mg}}{\mathrm{dl}}\right)$

Data were analyzed using SPSS 17 and p-value of $<$ 0.05 was considered as significant.

\section{RESULT}

During the 6 months of study period, total of 88 pregnant women with term pregnancy were enrolled in the study (44 preelamptic patients and 44 normotensive control). Age and gestational age was matching and there was significant difference in blood pressure and 24 hours calciuria $(\mathrm{p}<0.001)$. [Table-1]

Table-1: Distribution of mean age, pressure and calciuria

\begin{tabular}{|lccl|}
\hline & \multicolumn{2}{c}{ Mean \pm SD } & p-value \\
& \multicolumn{1}{c}{ Case } & Control & p-val \\
\hline Age (years) & $25.64 \pm 6.07$ & $25.41 \pm 5.70$ & 0.857 \\
$\begin{array}{l}\text { Gestational age } \\
\text { (weeks) }\end{array}$ & $38.48 \pm 1.46$ & $39.00 \pm 1.56$ & 0.107 \\
$\begin{array}{l}\text { Systolic BP } \\
\text { (mmHg) }\end{array}$ & $146.36 \pm$ & $108.64 \pm 9.30$ & $<0.001$ \\
$\begin{array}{l}\text { Diastolic BP } \\
\text { (mmHg) }\end{array}$ & $98.18 \pm 8.43$ & $70.00 \pm 8.35$ & $<0.001$ \\
$\begin{array}{l}\text { Mean arterial } \\
\text { pressure }\end{array}$ & $116.29 \pm$ & $82.88 \pm 7.35$ & $<0.001$ \\
(mmHg) & 10.81 & & \\
24 hours urine & $77.92 \pm$ & $177.66 \pm$ & $<0.001$ \\
calcium (mg) & 48.61 & 69.21 & \\
\hline
\end{tabular}

Among 44 patients in PE group, 11 had impending signs like headache, epigastric pain and blurring of vision, 8 patients had IUGR, 5 had oliguria and 2 patients presented with HELLP syndrome. When the 24 hours urine calcium excretion was compared among the patient with one and more than one features of severity of PE. The patients with more than one features of severity had slightly decreased 24 hours urine calcium excretion compared to the patients who had only one feature of severity ( $61.6 \mathrm{mg} / 24 \mathrm{hrs} \mathrm{Vs}$ $65.63 \mathrm{mg} / 24 \mathrm{hrs}$ ).[Figure-1]

Fig 1: Calciuria in relation to features of severity

The mean calcium excretion among the patients with proteinuria $3+(\mathrm{n}=11)$ was $54.02 \mathrm{mg} / 24 \mathrm{hrs}$ which was lower in compared to pateints with proteinuria $2+$ $(n=12)$ and $1+(n=21)$, among whom the calcium excretion was $76.19 \mathrm{mg} / 24 \mathrm{hrs}$ and $91.43 \mathrm{mg} / 24 \mathrm{hrs}$ respectively. [Table-2]

Table 2: Proteinuria in pre-eclampsia

\begin{tabular}{|llll|}
\hline PROTEINURIA & \multicolumn{4}{l}{ Calciuria $(\mathrm{mg} / 24 \mathrm{hrs})$} \\
(DETECTEDBY & Max & Min & Mean \\
SULFOSALISYLIC ACID) & & & \\
\hline$+1(0.3 \mathrm{gm} / \mathrm{dl})$ & 160 & 20.8 & 91.43 \\
$+2(1 \mathrm{gm} / \mathrm{dl})$ & 250 & 34.5 & 76.19 \\
$+3(3 \mathrm{gm} / \mathrm{dl})$ & 174 & 31 & 54.02 \\
\hline
\end{tabular}

\section{DISCUSSION}

The present study has been taken up to establish the relation between preeclampsia and the 24 hours urine excretion pattern which is an inexpensive method to evaluate the severity of the disease and also can be of some diagnostic and prognostic significance.

Worldwide, pre-eclampsia remains a leading cause of maternal mortality estimating $10-15 \%$ of the 500,000 maternal deaths each year caused by hypertensive diseases of pregnancy. ${ }^{6}$ The maternal mortality in Nepal was 281 per 1,00,000 live birth, hypertensive disorder in pregnancy being the second most common cause. $^{7}$

Preeclampsia has been dubbed the "disease of theories". Abnormal placentation and placental vascular insufficiency are core features of preeclampsia. $^{8,9}$

Calcium homeostasis is altered in women with preeclampsia. It may only reflect renal compromise because of hypertension or may be the result of reductions in renal prostaglandins. It could also be the result of reduced glomerular filtration rate, which appears at the same time as proteinuria. It has been speculated that hypocalciuria may result from decreased dietary intake, decreased intestinal absorption, increased calcium uptake by the fetus and placenta, intrinsic renal tubular dysfunction, or high intracellular calcium.

It has been reported that hypocalciuria predicts preeclampsia long before clinical manifestations exist. $^{10-14}$ 
During this study period of 6 months, preeclampsia was found to complicate 3\% of pregnancies,comparable to the study by Annath $\mathrm{CV}{ }^{14}$ and Caren G Solomon 8 (incidence of 3.4-3.5), Alessia Mammaro et al(incidence of $2-3 \%)^{15}$, and Gaber $\mathrm{M}$ who reported the incidence of 3-5\% ${ }^{16}$ but varied from the study by Szmidt- Adjide et al $(7-10 \%)^{1}$, Sibai $(5.3 \%)^{17}$ and Villar et al (9\%). ${ }^{18}$ The disparity in the incidence might be due the variation in ethnicity, socioeconomic as well as intellectual status and health awareness. The incidence can also be influenced by the number of study population and the timed period.

Majority of the patient in this study i.e. 26 among 44 PE patients i.e. 59\% were nulliparous. This result complimented that result of Gasner $(63 \%)^{5}$, Ramos $(82 \%)^{2}$, Cicih Opitasari $(78 \%)^{19}$ and Al-Mulhim $(42 \%)^{20}$. Similarly, 55\% (24 patients) were at 37-38 weeks of gestation, followed by $34 \%$ were at $39-40$ weeks of gestation and $11 \%$ were at $>40$ weeks of gestation which is comparable to the gestation age evidenced in the study by Uzma $\mathrm{S}$ et $\mathrm{al}^{21}(36.2 \pm 2.2$ weeks) and Huikeshoven FJM et al. ${ }^{22}$ However, the current study was done only among the term pregnant women $>37$ weeks of gestation, this cannot represent the overall incidence of PE.

In this study, Among the patient with MAP (Mean Arterial Pressure) $\geq 110 \mathrm{mmHg}$, mean urinary calcium excretion in were $73.55 \mathrm{mg} / 24 \mathrm{hrs}(\max .250$ $\mathrm{mg} / 24 \mathrm{hrs}$ and $\mathrm{min} 20.8 \mathrm{mg} / 24 \mathrm{hrs}$ ), lesser in compared to the patient with MAP $<110$ which was $92.79 \mathrm{mg} / 24$ hrs mmHg (max. $210 \mathrm{mg} / 24 \mathrm{hrs}$ and min. $34 \mathrm{mg} / 24$ hrs) which was comparable to the study by Sirohiwal
D et al ${ }^{13}$, Rose Gasner ${ }^{5}$, Huikeshoven FJM et al ${ }^{22}$ and Sanchez Ramos et al ${ }^{2}$. This concluded that calciuria decreased with the increasing MAP, this may also denotes that severity of Preeclampsia as the MAP increased.

When 24 hours urine calcium excretion was compared in this sutdy, the patients with more than one features of severity had slightly decreased 24 hours urine calcium excretion compared to the patients who had only one feature of severity $(61.6 \mathrm{mg} / 24 \mathrm{hrs}$ Vs 65.63 $\mathrm{mg} / 24 \mathrm{hrs}$ ) similar to the study by Gasner R et al ${ }^{5}$, Tubbergen $\mathrm{P}$ et $\mathrm{al}^{9}$, Bhattacharya $\mathrm{S}$ and Campbell $\mathrm{DM}^{23}$.

Finally, when the calciuria was compared among the two groups (the PE group and the control normotensive group, the mean calciuria in the study group of preeclamptic patients was $77.92 \mathrm{mg} / 24 \mathrm{hrs}$ with the range of $20.8-250 \mathrm{mg} / 24 \mathrm{hrs}$ while in the control group of normotensive patients that calciuria was found to be $177.6591 \mathrm{mg} / 24 \mathrm{hrs}$ with the range of $58-320 \mathrm{mg} / 24 \mathrm{hrs}$.

\section{CONCLUSIONS}

This study shows that the preeclamptic patients excrete significantly lower amount of urinary calcium and that the urinary calcium levels decrease with the severity of preeclampsia. It also concluded that measurement of 24 hours urinary calcium excretion has an advantage of diagnosing the severity of preeclampsia which may further help in screening the patient with severe disease and early management in order to reduce the maternal and neonatal morbidity and mortality.

\section{REFERENCES}

1. Szmidt-Adjide V, Vendittelli F, David S, Bredent-Bnagou J, Janky E. Calciuria and preeclampsia: A case-control study. Eur J Obs \& Gyne and Repro Bio. 2006;12-5:193-98.

2. Ramos JGL, Martins-Costa SH, Kessler JB, Barros E. Calciuria and preeclampsia. Braz J Med and Bio Research. 1998;31(4):519-22.

3. Bethesda. Global Burden of Disease for the Year 2001 by World Bank Region, for Use in Disease Control Priorities in Developing Countries, National Institute Of health : WHO. Make every mother and child count. World Health Report, 2005, Geneva: World Health Organization. 2005, 2nd edition.

4. Khedun SM, Moodler J, Naiker T. Drug management of hypertensive disorders of pregnancy. Pharmacol Ther. 1997;74(2):221-58

5. Gasner R, Valerio E, Veltorazzi J, Barros EV, Martins SH, Jose GL et al. Calciuria and Preeclampsia: A case control study. Obstet Gynaecol Res. 2012;38(4):674-80.

6. Himgiri JR. Estimation of urinary calcium as a predictor of pre-eclampsia. National Journal of Medical Sciences. 2014;3(1):1-4

7. Subedi BK, Pradhan AJ, Hulton L. Nepal maternal mortality and morbidity Study. NJOG. 2010;15(14).

8. Solmon CG, Seely EW. Preeclampsia searching for the cause. N Engl J Med. 2004;350: 641-2.

9. Tubbergen P, Lachmeijer AMA, Althuisius SM, Vlak MEJ, Van Geijn HP, Dekker GA. Change in paternity: a risk factor for preeclampsia in multiparous women? J Reprod Immunol.1999;45(1):81-8.

10. Khatun A, Kirtania K, Shima TZ, Ferdousi S, A Shahnaz, Yasmin F et al. Association of serum calcium and 24 hours urinary excretion of calcium in the patients of preeclampsia. Bangladesh J Med Biochem. 2010;3(2):57-60.

11. Vahdat M, Kashanian M, Sariri E, Mehdinia M. Evaluation of the value of calcium to creatinine ratio for predicting of preeclampsia. J Matern Fetal Neonatal Med. 2012;25(12):27934. 
12. Suarez VR, Juan GT, Juan MM. Urinary calcium in asymptomatic primigravidas who later developed preeclampsia. Obstetrics \& Gynecology.1996;87(1):1-62.

13. Sirohiwal D, Dahiya K, Khaneja N. Use of 24 hour urinary protein and calcium for prediction of preeclampsia.Taiwan $\mathrm{J}$ Obstet Gynecol. 2009;48(2):113-115

14. Ananth CV.Pre-eclampsia rates in the United States, 19802010: age-period-cohort analysis. BMJ. 2013;347:f6564.

15. Mammaro A, Carrara S, Cavaliere A, Ermito S, Dinatale A Maria E et al. Hypertensive Disorders of Pregnancy. J Prenat Med. 2009;3(1):1-5.

16. Gaber M. comparison between measurements of serum calcium, creatinine and uric acid in normal pregnancy and severe preeclamspsia. AAMJ. 2013;11(2):103-13

17. Sibai BM, Ewell M, Levine RJ, Klebanoff MA, Esterlitz J, Catalano PM et al. Risk factors associated with preeclampsia in healthy nulliparous women: A Prospective multicenter study. Am J Obstet Gynecol. 1997;177(5):1003-10.

18. Villar J, Abdel AH, Merialdi M, Mathai M, Ali MM, Zavaleta $\mathrm{N}$ et al. World Health Organization randomized trial of calcium supplementation among low calcium intake pregnant women. Am J Obtet Gynecol. 2006;194(3):639-649.

19. Cicih O, Lelly A. Parity, education level and risk for preeclampsia in selected hospitals in Jakarta. Health Science Indones. 2014;1:35-9.

20. Al-Mulhim AA, Abu-Heija A, Al-Jamma F, El-Harith HA Pre-eclampsia: maternal risk factors and perinatal outcome. See comment in PubMed Commons belowFetal Diagn Ther. 2003;18(4):275-80.

21. Uzma S,Hatcher J, Shamsi A, Zuberi N, Qadri Z, Saleem S. A mulicentre matched case control study of risk factors for Preeclampsia in healthy women in Pakistan. BMC Women's Health. 2010;30:10:14

22. Trans JM, Huikeshoven FJM, Zuiderhoudt. Hypocalciuria in hypertensive disorder in pregnancy and how to measure it. Eur J Obstet Gynecol Reprod Biol. 1990;36:81-85

23. Bhattacharya S, Campbell severe complications of Pregnancy. 2005;24(2):181-90

DM. The incidence of preeclampsia. Hypertens 